\title{
人物追従による移動ロボットの環境地図生成
}

\author{
○中本 秀一，西山 学，十倉 征司，園浦 隆史，大賀 淳一郎， \\ 香月 理絵, 尾崎 文夫 (東芝 研究開発センター)
}

\section{Development of Mobile Robot that Builds Map by Following Person}

*Hideichi NAKAMOTO, Manabu NISHIYAMA, Seiji TOKURA, Takafumi SONOURA, Junichiro OOGA, Rie KATSUKI and Fumio OZAKI

Toshiba Corporate R\&D Center, hideichi.nakamoto@toshiba.co.jp

\begin{abstract}
This paper describes the easy and efficient environmental map building method of gaining a destination and a picture landmark position, by following person. The technique of Augmented Reality in which the processing time in a recognition phase was quick was used for picture landmark detection from the scene. The map building experiment was conducted using mobile robot ApriAttenda ${ }^{\mathrm{TM}}$ in Toshiba Science Museum.
\end{abstract}

Key Words: mobile robot, map building, person following, localization

\section{1. はじめに}

これまで，周囲形状や画像を基に構成される環境地図を用い たロボットの移動機能について多くの研究がされているが，環 境地図の入力を人間が手動で行わなければならないという問題 があった. そこで, 我々は, ロボットが自動で壁沿いあるいは フリースペースを見つけて移動して地図を生成する機能が開発 してきた[1].しかし，施設などの広い場所では，ロボットが自 律移動を行っても必要な筒所の環境地図を必ず獲得できるとは 限らず，時間もかかっていた．さらに，広い場所では画像デー 夕も膨大になり，処理コストがかかるという問題があった. そ こで, より簡単で, 効率の良い環境地図生成方法として, Fig.1 に示すように人が誘導することにより，巡回箇所及び目的地の 画像ランドマーク位置を教える機能を提案する.ロボットは人 物追従を行うと同時に，必要な箇所の周囲形状を獲得し，人に 示された目的地の画像ランドマークを登録する.この時, 口ボ ットが自ら画像中からランドマークを決めるのが望ましいが, 今回は，その前段階として，環境特徵点を利用した平面実物体 の画像認識を用い，あらかじめ登録された画像ランドマークを 検出し，その画像ランドマークが環境地図でどの位置にあるか を登録する機能について述べる. いったん地図上に画像ランド マークの位置が登録されれば，次回からは同様の処理により， この画像ランドマークを検出して自己位置同定を行える.なお, 実験はNEDO「次世代ロボット実用化プロジェクト」で開発し たお供ロボットApriAttenda ${ }^{\mathrm{TM}}[2]$ を用いて行った。

\section{2. 環境特徴点を利用した平面実物体の画像認識}

近年，拡張現実感技術の分野において，特に照明変化に対す るロバスト性，リアルタイム性を追求した，画像中からの物体 位置認識の研究がさかんに行われている[3]. これを参考にして， 学習によって作成した識別木を用いてランドマーク検出を行っ た. 本研究での検出方法の特徵は, 学習段階での前処理に時間 を割くことで, 特徴点抽出とマッチングの時間を短縮し, 高速 に平面実物体の位置姿勢を推定することにある.

これをもとに, シーン中の学習した平面実物体ランドマーク の位置姿勢を推定するシステムを構築した．平面実物体ランド マークとしたのは, 科学館の展示品パネルや美術館の絵画など をランドマークとして利用でき, 平面という拘束のもとに様々 な方向からランドマークを見たときの認識処理が簡単になり， ロボットの相対位置姿勢を推定しやすいからである.

学習段階ではまず，与えられた学習画像から，特徴点を抽出 する. そして, その特徴点を中心とする画像小領域のアフィン 変換画像をもとに識別木を構築する.
認識段階では，人力画像から特徵点を抽出し，その特徵点を 中心とする画像小領域を識別木に入れ，入力画像と学習画像中 の特徴点のマッチングを行う。マッチング結果には，対応が失 敗したものも含まれており，この影響を抑えて，正しいランド マーク平面とカメラ画像座標系間のホモグラフィ行列を求めな ければならない.このため, RANSAC[4]を用いて, ランダムに 取り出した $6 つ の$ 対応をもとにホモグラフィ行列を最小二乗法 を用いて求め, 他の対応に対してもこの行列を適用し, 誤差が 一定範囲以内なら正しいと判別する.

Fig. 2 に処理結果を示す. この実験では学習対象としてポスタ 一を用いた. 左がその学習画像, 右が認識対象となるカメラか らの入力画像である.ここでは床に置いたポスターが写ってい るシーンを入力画像とした. 緑色線は学習画像の特徵点と入力 画像中の特徵点との間で得られた対応を示す．紫色線は，変換 行列を計算した後, 学習画像の 4 隅の座標值を入力画像座標系 に変換し，それらを結んだ線である．このようにシーンから対 象物を切り出すことができている.

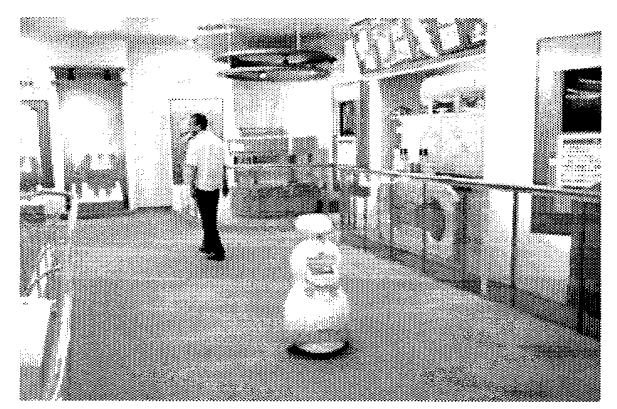

Fig.1 Experimental Scene by ApriAttenda ${ }^{\mathrm{TM}}$

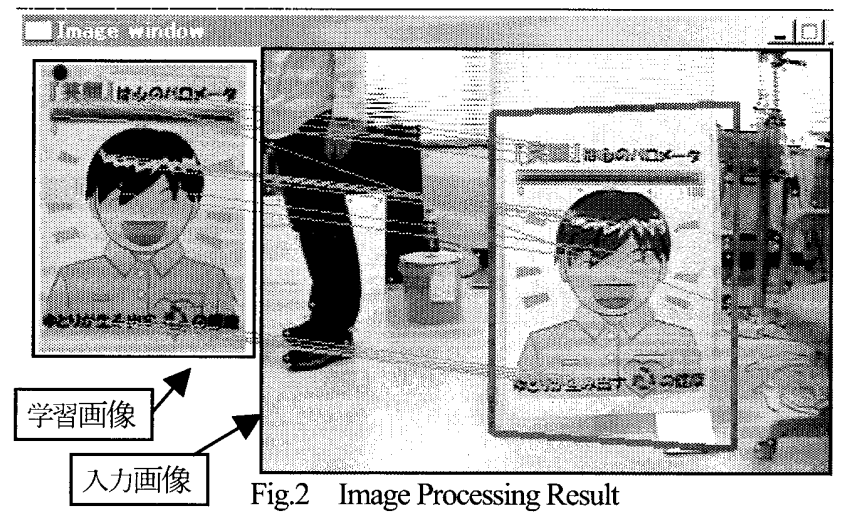

[No. 06-4] Proceedings of the 2006 JSME Conference on Robotics and Mechatronics, Waseda, Japan, May 26-28, 2006 $1 \mathrm{~A} 1-\mathrm{E} 31(1)$ 


\section{3. 地図生成，ランドマーク認識実験}

実験では, Fig.3に示す科学館の中を, ロボットが人を追従し て館内を一周し，レーザレンジファインダで周囲環境をスキャ ンして地図の生成を行った．地図生成結果を Fig.4 に示す．生 成したグリッドマップは，1グリッドの大きさ $20 \mathrm{~cm} \times 20 \mathrm{~cm}$ で あり，白い部分ほどフリースペースである可能性が高い：この 結果をみると，人に追従して館内を一周するのみで， $18 \mathrm{~m} \times 14$ mの空間のスケール，形状を地図上でほぼ再現できている。 ロ ボットはこの地図をもとに，次回から経路を生成して巡回する ことができる.

また，あらかじめ覚えておいた展示パネル画像の認識の様子 を, Fig.5, Fig.6に示す.これはロボットを展示パネルの前まで 連れて行き，パネルを認識させたものである。 それぞれの図の 黄色い枠で囲まれた左が学習画像，右が認識対象となる人力画 像で，紫色の枠がパネルを検出した範囲を示している. このよ うにシーンからパネルを切り出すことができ，識別木を切り替 えることで，各ランドマークを区別しての認識が可能である.

ランドマークとカメラの位置関係による認識率の評価実験を 行うと, 距離については正面で最大 $3.5[\mathrm{~m}]$ まで認識可能であっ た.この科学館のような広い施設での使用を考えると, 巡回中 に次の目的地にあるランドマークを画像中に捕らえて移動する には，検出距離が短く，3.5[m]まで近づかなければならない． よって，今のアルゴリズムではスケール変化，特に遠距離から の検出が課題である. また，角度については，パネル正面方向 から最大 $\pm 50[\mathrm{deg}]$ まで認識可能であり, アフィン変換を用いる 学習原理から言っても, 本アルゴリズムは角度に対してはロバ ストにランドマークを検出できている.

\section{4. まとめ}

本稿では，広い複雑な場所でも，効率良く環境地図を生成す る方法として，ロボットを人が誘導することにより，巡回籄所 及び画像ランドマーク位置を覚える機能について述べた. シー ンからのランドマーク抽出には，照明変化に対するロバスト性 や実時間性から，ロボットビジョンとの親和性が高いと考えら れる拡張現実感分野から，学習段階に処理時間を割くことで, 認識フェーズでの処理速度が高い, 自己位置推定法を取り入れ た. 今後この方法を利用して，ロボットが自律的にランドマい クを決める機能を開発し，人が目的地まで誘導すれば，ロボッ トが自律的にシーンからランドマークを決めて学習できるよう にする予定である. 例えば，距離センサなどで平面を検出し， その平面の画像特徴点の数が多く, 全特徴点の座標值の平均が 画像中心に近い時，その画像をランドマーク候補とする処理が 考えられる.さらに，ランドマークを3次元に拡張し，平面だ けではなく, 物体形状計測と組合せて, 立体へも認識対象範囲 を拡大することも考えられる。

\section{参考文献}

[1] Sildomar T. Monteiro, Hideichi Nakamoto, Hideki Ogawa and Nobuto Matsuhira, "Robust mobile robot map building using sonar and vision Evolving the navigation abilities of the ApriAlpha. home robot" ROBOMEC'05, 2P1-N-52,2005

[2] 吉見,中本,園浦,西山,十倉,尾崎,松日楽,溝口;"お供ロボット AprilAttenda ${ }^{\mathrm{TM}}$ の全体システム構成". RSJ2005, 3B35, 2005

[3] http://www.hitl.washington.edu/artoolkit/

[4] M. A. Fischler, R. C. Bolles. Random Sample Consensus: A Paradigm for Model Fitting with Applications to Image Analysis and Automated Cartography. Comm. of the ACM, Vol 24, pp 381-395, June 1981.

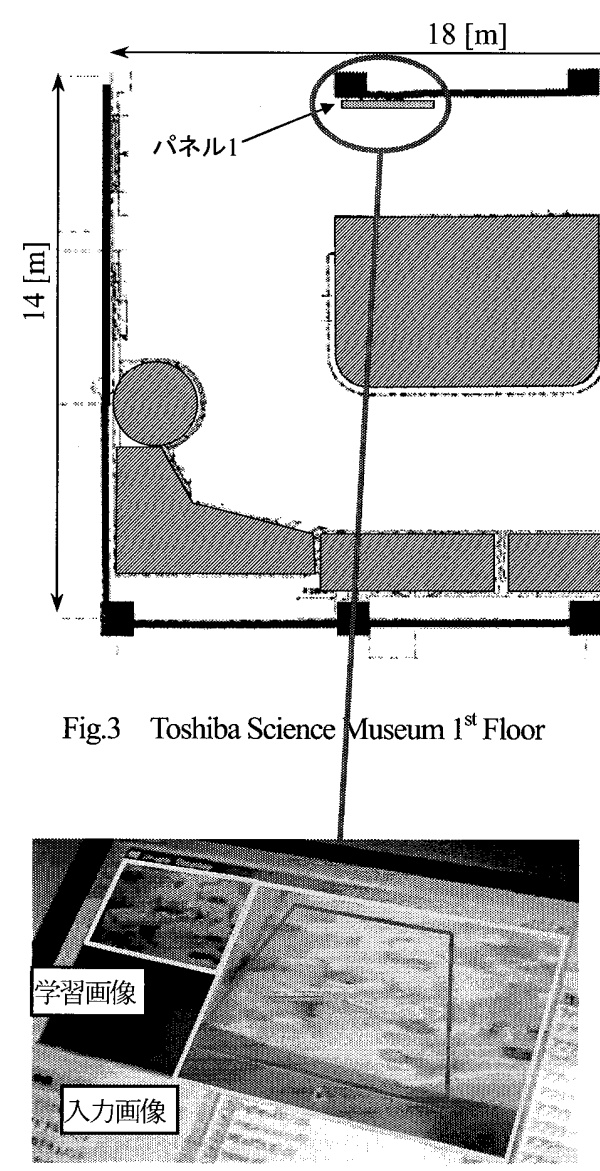

Fig.5 Landmark (Panel 1) Detection

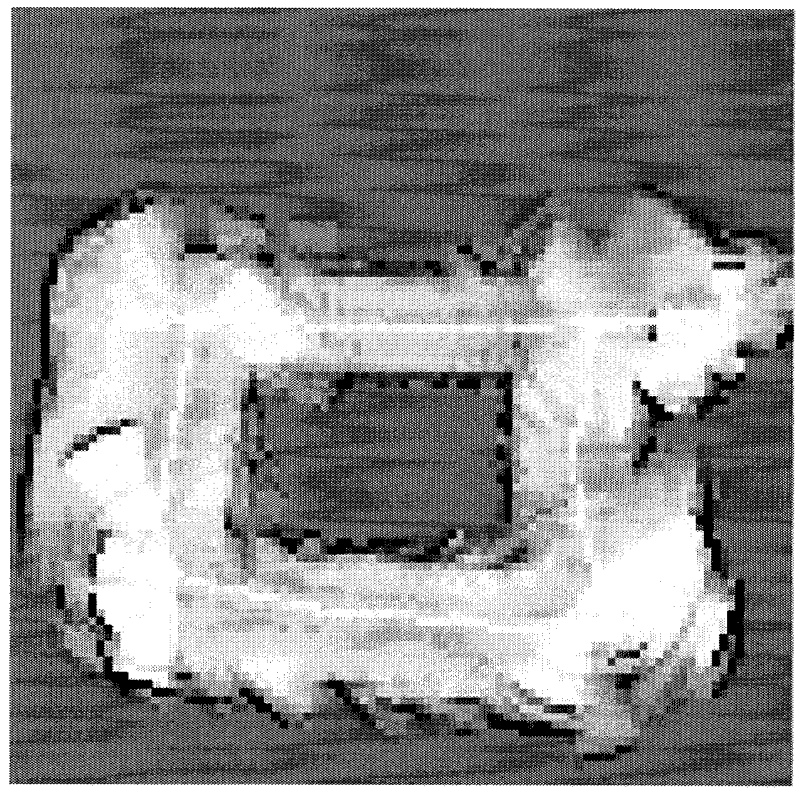

Fig.4 Grid Map of Toshiba Science Museum $1^{\text {st }}$ Floor 